\title{
PENGARUH PEMBERIAN AIR KELAPA MUDA TERHADAP PENURUNAN TEKANAN DARAH PADA PENDERITA HIPERTENSI DI WILAYAH KERJA PUSKESMAS LANRISANG KABUPATEN PINRANG
}

\section{Effect of Young Coconut Water on Decreasing Blood Pressure on Hypertension Patients in Lanrisang Community Health Center in Pinrang District}

\author{
Fandi Andika ${ }^{1}$, Haniarti ${ }^{2}$, Amir Patintingan ${ }^{3}$ \\ ${ }^{1}$ Mahasiswa Konsentrasi Gizi Fakultas Ilmu Kesehatan Universitas Muhammadiyah Parepare \\ ${ }^{2}$ Dosen Program Studi Kesehatan Masyarakat Universitas Muhammadiyah Parepare \\ ${ }^{3}$ Dosen Program Studi Kesehatan Masyarakat Universitas Muhammadiyah Parepare \\ (fandiandika20gmail.com)
}

\begin{abstract}
ABSTRAK
Penyakit hipertensi dapat dikendalikan dengan pengobatan non farmalokogis salah satunya air kelapa muda, karena kandungan kalium yang terdapat dalam air kelapa muda sangat bermanfaat untuk menurunkan tekanan darah sistolik dan diastolik. Tujuan penelitian adalah untuk mengetahui pengaruh pemberian air kelapa muda terhadap penurunan tekanan darah pada penderita hipertensi di Wilayah Kerja Puskesmas Lanrisang Kabupaten Pinrang.Jenis penelitian yang digunakan adalah eksprimen kuasi (quasi ekspriment). Dengan rancangan one group pre test-post test. Variabel independen adalah pemberian air kelapa muda dan variabel dependen adalah penurunan tekanan darah pada penderita hipertensi. Sampelnya sebanyak 52 responden dan teknik sampling yang digunakan adalah accidental sampling. Penelitian ini dilakukan di Wilayah Kerja Puskesmas Lanrisang Kabupaten Pinrang pada Tanggal 25 Maret sampai 30 Juli 2018. Hasil penelitian ini dapat disimpukan bahwa ada pengaruh pemberian air kelapa muda terhadap penurunan tekanan darah pada penderita hipertensi di Wilayah Kerja Puskesmas Lanrisang Kabupaten Pinrang.

Kata Kunci : Tekanan Darah, Hipertensi , Air Kelapa Muda.

\section{ABSTRACT}

Hypertension can be controlled with non pharmalocogical treatment, one of them is young coconut water, because the content of potassium contained in young coconut water is very useful to reduce systolic and diastolic blood pressure. The purpose of the study was to determine the effect of young coconut water on blood pressure reduction in hypertensive patients in the Lanrisang Community Health Center in Pinrang District. The type of research used is quasi experimental. With the design of one group pre test - post test. The independent variable is the administration of young coconut water and the dependent variable is a decrease in blood pressure in patients with hypertension. The sample of 52 respondents and the sampling technique used was accidental sampling. This research was conducted in the Lanrisang Community Health Center Work Area of Pinrang Regency on March 25 to July 30, 2018.The results of this study can be concluded that there is an effect of giving young coconut water to decrease blood pressure in patients with hypertension in the Lanrisang Health Center community, Pinrang Regency.
\end{abstract}

Keyword : Blood Pressure, Hypertention, Young Coconut Water 


\section{PENDAHULUAN}

Hipertensi merupakan salah satu faktor resiko utama penyakit Organization (WHO) tahun 2008 menunjukkan bahwa prevalensi hipertensi pada orang dewasa berusia $\geq 25$ tahun di dunia sekitar 38,4\%. Trend penyakit hipertensi pun terus meningkat dari tahun ke tahun dengan terjadinya transisi epidemologi. Berdasarkan data $W H O$ terjadi peningkatan kasus sebanyak 400 kasus dari tahun 1980 sampai dengan tahun 2008 dan di prediksi kasus hipertensi akan mencapai 1,56 miliar di tahun 2025.

Penyakit hipertensi ini berbahaya karena tidak ada gejala khas sebagai peringatan, disebut juga silent killer. Banyak orang memiliki gejala hipertensi yang tidak terdeteksi karena orang tersebut merasa sehat dan energik sehingga sebagian besar kasus hipertensi di masyarakat belum terdiagnosis. Satu dari tiga orang dewasa memiliki peningkatan pada tekanan darahnya, hal ini merupakan suatu kondisi yang mengakibatkan setengah dari kematian akibat stroke dan serangan jantung di dunia. ${ }^{1}$

Menurut laporan Kemenkes (2015), bahwa hipertensi merupakan penyebab kematian nomor 3 setelah stroke dan tuberkulosis, dimana proporsi kematiannya mencapai $6,7 \%$ dari populasi kematian pada semua umur di Indonesia . Hasil Riset Kesehatan Dasar (Riskesdas) tahun 2015 oleh Badan Penelitian dan Pengembangan Kemenkes Republik Indonesia bahkan menunjukkan prevalensi hipertensinasional sebesar 31,7\%. Dari jumlah itu, 60\% penderita hipertensi berakhir pada stroke, sedangkan sisanya pada jantung, gagal ginjal, dan kebutaan.

Data yang diperoleh dari Instalasi Rekam Medik RUSP Dr. Wahidin di Sudirohusodo Makassar, tercatat bahwa jumlah pasien hipertensi untuk rawat jalan tahun 2007 sebanyak 5823 kasus $(1,68 \%)$, tahun 2008 sebanyak 5508 kasus (3,34\%), dan tahun 2009 sebanyak 5655 kasus $(4,66 \%)$ dan tahun 2010 sebanyak 1880 kasus (1,2\%). Dimana pada tahun 2010 di rumah sakit tersebut, hipertensi menempati posisi pertama untuk kasus terbanyak pada pasien rawat jalan. Berkembangnya hipertensi sangat di pengaruh oleh banyak faktor, antara lain kurangnya aktivitas fisik, kebiasaan merokok, stress, riwayat keluarga, kebiasaan mengkomsumsi makanan tinggi lemak, dan komsumsi makanan rendah kalium dan natrium tinggi. ${ }^{2}$

Berdasarkan data yang di peroleh dari Puskesmas Lanrisang Kabupaten Pinrang, terdapat beberapa penyakit yang diderita oleh masyarakat yaitu hipertensi, batuk, gastritis, diare, ispa, gout, demam, dermatitis dan diabetes mellitus. Penyakit hipertensi ini menduduki peringkat ketiga penyakit dengan penderita terbanyak yaitu 1115 dengan jumlah laki-laki yang menderita sebanyak 489 orang dan perempuan sebanyak 626 orang pada tahun 2017. 
Hipertensi dibiarkan terjadi terusmenerus dalam kurun waktu yang lama akan berbahaya bagi orang yang sudah menderita hipertensi sehingga dapat menimbulkan komplikasi. Komplikasi hipertensi dapat mengenai organ jantung, otak (serebrovaskuler), mata, dan ginjal. ${ }^{3}$

Hipertensi dapat dikendalikan dengan pengobatan farmakologi dan non farmakologi. Pengobatan farmakologi merupakan pengobatan dengan menggunakan obat anti hipertensi untuk menurunkan tekanan darah diantaranya seperti ACE inhibitor, diuretik, antagonis kalsium, dan vasodilator. Sedangkan pengobatan non farmakologi merupakan pengobatan tanpa menggunakan obat-obatan. ${ }^{3}$

Salah satu bentuk pengobatan non farmakologi hipertensi yaitu menggunakan air kelapa muda, air kelapa muda merupakan air yang biasa ditemukan pada buah kelapa yang masih mudah dan memiliki rasa yang manis, air kelapa mengandung beberapa kandungan seperti gula, vitamin, kalsium dan kalium. Konsumsi bahan makanan dengan kandungan kalium tinggi dan natrium rendah penting untuk mempertahankan tekanan darah dalam batas normal. Air kelapa muda mengandung unsur kalium yang tinggi (sekitar $291 \mathrm{mg} / 100 \mathrm{ml}$ ), air kelapa umur 6-8 bulan mempunyai kandungan kadar kalium tertinggi dan kadar natrium terendah. $^{4}$

Peran kalium dalam menurunkan tekanan darah diperkirakan melalui mekanisme natriuresis di ginjal, endhotelium-dependent vasodilation, dan juga melalui efek sentral yaitu penurunan aktivitas renin angiotensin aldesteron (RAA) dan peningkatan $\mathrm{Na}$ pump yang menurunkan aktivitas saraf simpatis. Kalium merupakan unsur kimia dalam tabel periodik yang memiliki lambang $\mathrm{K}+$ dengan nomor atom 19 daan berat molekul 39,10 g/mol. Kalium (K+) merupakan kation utama pada cairan intraseluler (CIS), 98\% K+ tubuh berada dalam sel, sisanya $2 \%$ berada dalam cairan ekstraseluler (CES). Kalium membentuk 0,35\% dari total berat badan atau sekitar 245 gram pasa orang dengan berat badan $70 \mathrm{~kg}{ }^{4}$

Asupan kalium air kelapa hijau mudah membantu mengatasi tekanan darah tinggi. Kalium sangat bermanfaat untuk menurunkan tekanan darah sistolik dan diastolik dengan menghambat pelepasan rennin sehingga membantu peningkatan ekskresi natrium dan air. Kalium yang sangat tinggi akan mengontrol tekanan darah yang semula tinggi menjadi normal. ${ }^{5}$

Kecukupan kalium sangat penting bagi semua orang terutama bagi penderita hipertensi. Penambahan kalium dari makanan sehari-hari termasuk yang dari air kelapa muda sangat bermanfaat untuk meningkatkan rasio kalium terhadap sodium yang bermanfaat untuk menurunkan tekanan darah. Itulah menjadi salah satu alasan mengapa pasien hipertensi dianjurkan mengkonsumsi air kelapa secara rutin. Air kelapa muda merupakan minuman 
terbaik bagi penderita hipertensi karena memiliki kandungan kalium yang sangat tinggi dan sodium yang sangat rendah. ${ }^{5}$

Di Indonesia untuk mendapatkan air kelapa mudah dan murah, hal ini disebabkan banyaknya tumbuhan kelapa di Indonesia. Air kelapa muda yang berasal dari buah kelapa yang berumur lebih dari 7 bulan biasanya memiliki rasa yang istimewa. Rasa manisnya cukup dan didukung oleh rasa kelapa yang khas. Pada orang awam, air kelapa muda memiliki efek dalam menetralkan racun-racun dalam tubuh. Selain itu air kelapa ini mengandung berbagi zat makanan yang penting, seperti vitamin dan berbagai macam mineral.

Pada penelitian yang dilakukan oleh Gandes Tricara dkk 2014, dimana hasil dari penelitiannya yaitu ada pengaruh air kelapa muda terhadap penurunan tekanan darah penderita hipertensi di Desa Kauman Kecamatan Kabuh Kabupaten Jombang. ${ }^{6}$

Berdasarkan latar belakang tersebut maka peneliti tertarik untuk melakukan penelitian di Wilayah Kerja Puskesmas Lanrisang Kabupaten Pinrang dengan judul Pengaruh Pemberian Air Kelapa Muda terhadap Penurunan Tekanan Darah pada Penderita Hipertensi di Wilayah Kerja Puskesmas Lanrisang Kabupaten Pinrang.

Tujuan penelitian ini adalah untuk mengetahui pengaruh pemberian air kelapa muda terhadap penurunan tekanan darah pada penderita hipertensi di Wilayah Kerja Puskesmas Lanrisang Kabupaten Pinrang.

\section{BAHAN DAN METODE}

Metode yang digunakan dalam penelitian ini adalah eksprimen kuasi (quasi ekspriment). Dengan rancangan" one group pre test - post test". Lokasi dalam penelitian adalah Wilayah Kerja Puskesmas Lanrisang Kabupaten Pinrang pada tanggal 25 Maret sampai 30 Juli 2018. Populasi dalam penelitian ini adalah sebanyak 1115 orang, untuk menentukan sampel digunakan rumus Lameshow, sehinnga didapatkan 52 sampel. Pengambilan sampel secara accidental sampling. Variabel independen adalah pemberian air kelapa muda dan variabel dependen adalah penurunan tekanan darah pada penderita hipertensi.

Data primer adalah data yang diambil dari responden atau sampel penelitian. Adapun data yang diambil berupa data umur penderita hipertensi, jenis kelamin dan hasil dari pengukuran tekanan darah. Sedangkan data sekunder adalah data yang diambil di Puskesmas Lanrisang Kabupaten Pinrang yang berkaitan dengan jumlah penderita hipertens di tahun 2017. Pengolahan Data dengan menggunakan alat elektronik melalui komputer dengan Program Statistical Product and Service Solution (SPSS) versi 24, dengan uji analisis Wilcoxon. 


\section{HASIL}

Hasil penelitian karakteristik responden berdasarkan umur yaitu kategori umur 30-39 tahun sebanyak 6 responden $(11,5 \%)$, umur 40 49 tahun sebanyak 8 responden $(15,4 \%)$, umur 50-59 sebanyak 20 responden (38,5\%), umur 6069 sebanyak 14 responden $(26,9 \%)$ dan umur > 70 sebanyak 4 responden $(7,7 \%)$. Sedangkan distribusi karakteristik responden berdasarkan jenis kelamin yaitu laki-laki sebanyak 20 responden $(38,5 \%)$, dan perempuan sebanyak 32 responden $(61,5 \%)$, yang dapat dilihat pada Tabel 1. Distribusi tekananan darah sistolik responden sebelum diberikan air kelapa muda pada Tabel 2 yaitu hipertensi derajat I sebanyak 41 responden $(78,8 \%)$ dan hipertensi derajat II sebanyak 11 responden $(21,2)$. Distribusi tekananan darah sistolik responden sesudah diberikan air kelapa muda pada tabel 3 yaitu optimal sebanyak 3 responden $(5,8 \%)$, normal 12 responden $(23,1 \%)$, pra hipertensi sebanyak 20 responden $(38,5)$ dan hipertensi derajat I sebanyak 17 responden( $32,7 \%)$.

Keadaan tekanan darah diastolic responden sebelum diberikan air kelapa muda pada tabel 4 yaitu normal sebanyak 2 orang $(3,8)$, hipertensi derajat I sebanyak 25 orang $(48,1)$ dan hipertensi derajat II sebanyak 25 orang $(48,1)$. Sedangkan tekanan darah diastolik sesudah diberikan air kelapa muda pada Tabel 5 yaitu optimal sebanyak 1 responden $(1,9)$, normal sebanyak 16 responden $(30,8)$, hipertensi derajat I sebanyak 25 responden dan hipertensi derajat II sebanyak 10 orang.

Skor rata-rata tekanan darah sistolik pre test yaitu 147,69 $\mathrm{mmHg}$ dengan standar deviasi 8,771 dan skor rata-rata tekanan darah sistolik post test yaitu $130,19 \mathrm{mmHg}$ dengan standar deviasi 9,598. Sedangkan skor rata rata tekanan darah diastolik pre test yaitu $94,42 \mathrm{mmHg}$ dengan standar deviasi 5,744 dan rata-rata tekanan darah diastolik post test yaitu 88,46 $\mathrm{mmHg}$ dengan standar deviasi 7,511 yang dapat dilihat pada Tabel 6 .

Hasil analisis menggunakan uji statistik Wilcoxon pada tabel 7 yaitu nilai signifikan sistolik 0,000 dan diastolik 0,000 yang artinya nilai $p<0,05$ dengan demikian dapat dikatakan bahwa ada pengaruh air kelapa muda terhadap penurunan tekanan darah pada penderita hipertensi di Wilayah Kerja Puskesmas Lanrisang Kabupaten pinrang.

\section{PEMBAHASAN}

Karakteristik berdasakan umur kategori penderita hipertensi tertinggi pada penelitian ini yaitu umur 50-59 tahun dengan 20 responden. Faktor yang memicu hipertensi sebagian besar dipengaruhi oleh usia yang bertambah, dimana usia juga mempengaruhi tekanan darah seseorang, dengan bertambahnya usia seseorang maka pembuluh darah akan cenderung kaku dan elastisitasnya akan berkurang sehingga akan mengakibatkan tekanan darah meningkat. ${ }^{7}$ 
Karakteristik berdasarkan jenis kelamin dalam penelitian ini terdapat 20 responden yang berjenis kelamin laki-laki sedangkan yang 32 responden yang berjenis kelamin perempuan. Alasan terjadinya perbedaan tekanan darah berdasarkan jenis kelamin belum diketahui, namun diduga karena adanya penurunan hormon estrogen pada wanita setelah mengalami menopouse.

Menurut Kowalski (2010), perempuan lebih banyak mengalami hipertensi karena sifat dasar kaum wanita yang selalu mengedepankan kepentingan orang lain, keluarga, dan teman mereka diatas kepentingan sendiri menghalangi mereka mendapatkan perawatan medis pada saat muncul gejala awal penyakit kardiovaskular. Angka morbiditas dan kematian akibat serangan jantung, stroke, angioplasty, operasi bypass pada wanita lebih tinggi dari pada pria. Penyebabnya, perkembangan penyakit pada wanita jauh lebih cepat dari pada pria. Hipertensi membuat kaum wanita harus membayar lebih mahal dari pada pria. Resiko kambuhnya serangan jantung, stroke, dan kejadian kardiovaskular lain pada wanita meningkat sejalan dengan meningkatnya tekanan darah ${ }^{8}$

Peneliti melakukan pemeriksaan tekanan darah pada responden yang menderita hipertensi dan menyampaikan informasi mengenai tekanan darah tinggi atau hipertensi serta penyebab hipertensi dan cara pengobatan hipertensi, khususnya pengobatan secara non farmakologi, salah satu pengobatan non farmokologi yaitu dengan menggunakan air kelapa muda yang dapat digunakan untuk menurunkan dan mengontrol tekanan darah tinggi menjadi normal. Kemudian melakukan intervensi berupa pemberian air kelapa muda kepada responden selama satu minggu dengan frekuensi dua kali sehari, sebanyak $300 \mathrm{ml}$ dalam satu kali konsumsi. Sesuai dengan pendapat Atania (2013), bila ingin mendapatkan manfaat air kelapa muda dalam menurunkan tekanan darah tanpa merasakan efek samping maka konsumsi air kelapa yang disarankan adalah maksimal 2-3 gelas perhari.. Sesudah melakukan intervensi kemudian dilakukan pengukuran tekanan darah pada responden dengan tujuan untuk mengetahui apakah air kelapa muda dapat menurunkan tekanan darah pada penderita hipertensi.

Hasil pengukuran tekanan darah sistolik pada responden sebelum diberikan air kelapa muda yang tertinggi berada pada kategori hipertensi derajat I dengan 41 responden dan hipertensi derajat II dengan 11 responden, sedangkan hasil pengukuran tekanan darah sistolik sesudah diberikan air kelapa muda yang tertinggi berada pada kategori pra hipertensi dengan 20 responden dan hipertensi derajat II dengan 17 responden.

Hasil pengukuran tekanan darah diastolik sebelum diberikan air kelapa muda berada pada kategori hipertensi derajat I dan hipertensi derajat II dengan 25 responden sedangkan hasil pengukuran tekanan darah diastolik sesudah diberikan air kelapa muda yang 
tertinggi berada pada hipertensi derajat I dengan 25 responden dan normal dengan 16 responden.

Skor rata-rata tekanan darah sistolik pre test yaitu 147,69 $\mathrm{mmHg}$ dengan standar deviasi 8,771 dan skor rata-rata tekanan darah sistolik post test yaitu $130,19 \mathrm{mmHg}$ dengan standar deviasi 9,598. Sedangkan skor rata-rata tekanan darah diastolik pre test yaitu $94,42 \mathrm{mmHg}$ dengan standar deviasi 5,744 dan skor rata-rata tekanan darah diastolik post test yaitu 88,46 mmHg dengan standar deviasi 7,511.

Tekanan darah dapat meningkat disebabkan oleh beberapa faktor seperti hilangnya elastisitas jaringan pada usia tua, mengkonsumsi asupan garam yang tinggi, mengkonsumsi makanan berlemak, stress yang dialami dan beberapa responden sebelum dilakukan pengukuran tekanan darah sudah melakukan aktivitas yang banyak sehingga tekanan darah dapat meningkat.

Tekanan darah dapat menurun dapat dilihat dari beberapa faktor seperti kondisi respon tidak dalam keaadan stress saat dilakukan pengukuran tekanan darah, kurangnya responden yang mengkonsumsi asupan garam, kurangnya responden yang mengkonsumsi makanan berlemak dan juga beberapa responden (7 responden) yang mengkonsumsi obat anti hipertensi saat dilakukan penelitian, serta mengkonsumsi air kelapa muda dua kali dalam sehari selama satu minggu secara berkelanjutan, hal inilah yang dapat menurunkan tekanan darah pada responden dalam penelitian ini.
Air kelapa muda mengandung kadar kalium yang tinggi. Peran kalium dalam menurunkan tekanan darah diperkirakan melalui mekanisme natriuresis di ginjal, endhoteliumdependent vasodilatation, dan juga melalui efek sentral yaitu penurunan aktivitas renin angiotensin aldosteron (RAA) dan peningkatan neuronal Na pump yang menurunkan aktivitas saraf simpatis. ${ }^{4}$

Kalium merupakan mineral makro yang sangat penting bagi tubuh dan memiliki banyak fungsi, diantaranya adalah menjaga keseimbangan cairan tubuh, menyalurkan nutrisi ke dalam sel dan membuang sampah metabolit dari dalam sel, memelihara kesehatan otot dan saraf, membantu sekresi insulin ke dalam darah, memelihara fungsi normal jantung, serta membantu aktivitas lambung selama proses pencernaan makanan berlangsung. Ion kalium yang terkandung dalam air kelapa muda yang dapat menurunkan aktivitas simpatis sehingga terjadi penurunan frekuensi denyut jantung. ${ }^{1}$

Ion kalium juga merangsang dilatasi pembuluh darah dengan cara menurunkan potensial membran sehingga kontraksi otot polos dihambat, terjadi penurunan Total Peripheral Resistance (TPR) yang menyebabkan tekanan darah menurun. Selain itu, ion kalium dapat bertindak sebagai ACE inhibitor sehingga terjadi inhibisi produksi dari angiotensin II yang merupakan vasokonstriktor kuat dan menurunkan sekresi hormon aldosteron serta ADH (Anti Diuretic Hormone) oleh kelenjar 
hipofise. Penurunan sekresi hormon aldosteron berefek terhadap penurunan retensi garam dan air oleh ginjal, sedangkan penurunan $\mathrm{ADH}$ menyebabkan penurunan absorpsi air. Penurunan retensi garam dan air serta absorpsi air menyebabkan volume cairan intravaskuler menurun sehingga venous returnpun menurun. Dengan demikian, terjadi penurunan stroke volume dan cardiac output yang akan menyebabkan terjadinya penurunan tekanan darah. Teratur konsumsi air kelapa muda sesuai dengan takaran dan jadwal akan memberika dampak positif bagi penderita hipertensi. ${ }^{1}$

Hasil penelitian tersebut dapat dilihat bahwa adanya perbedaan yang signifikan antara tekananan darah responden sebelum diberikan air kelapa muda dan tekanan darah sesudah diberikan air kelapa muda, sehingga dapat diketahui bahwa ada pengaruh pemberian air kelapa muda terhadap penurunan tekanan darah pada penderita hipertensi. Hal ini dapat terjadi karena pengaruh air kelapa muda yang diberikan kepada responden.

Berdasarkan uji Wilcoxon diporelah hasil signifikan $p$ value $=$ sistolik 0,000 dan diastolik $0,000(p<0,05)$, hal ini menunjukkan bahwa nilai $p$ value lebih kecil dari standar signifikasi 0,05 maka Ha diterima dan $\mathrm{H} 0$ di tolak. Dengan demikian dapat dikatakan ada pengaruh pemberian air kelapa muda bagi penderita hipetensi di Wilayah Kerja Puskesmas Lanrisang Kabupaten Pinrang.
Hasil penelitian ini menunjukan adanya perbedaan tekanan darah yang signifikan antara tekanan darah sebelum dan sesudah diberikan air kelapa muda di Wilayah Kerja Puskesmas Lanrisang Kabupaten Pinrang. Perbedaan tersebut terjadi karena adanya mekanisme kontrol sistem saraf yang mempengaruhi kecepatan detak jantung dan perubahan tekanan darah yang menyusaikan agar sebanding dengan kecepatan pernapasan yang terjadi pada responden. Ini membuktikan bahwa meskipun hipertensi, tekanan darahnya dapat diturunkan dengan terapi non farmakologis, yaitu air kelapa muda yang mengandung kalium yang dapat membantu tekanan darah turun.

Sebagian besar responden pada penelitian menyatakan bahwa mereka mendapatakan ketenangan dan merasa lebih baik sesudah mengkonsumsi air kelapa muda dan ada juga responden yang menyatakan sakit kepala dan ketegangan otot yang mereka alami berekurang. Hal ini menunjukan bahwa mengkonsumsi air kelapa muda dapat membantu mengurangi resiko terjadinya tekanan darah tinggi.

Hasil penelitian ini juga menunjukan bahwa konsumsi air kelapa muda berpengaruh atau memiliki efek positif terhadap tekanan darah. Dengan demikian pada penelitian ini dapat dikatakan bahwa air kelapa muda terbukti mempengaruhi beban kerja jantung, pompa kalium-natrium dan mendatangkan ketenangan yang akhirnya berpengaruh terhadap tekanan 
darah. Oleh karena itu air kelapa muda efektif untuk membantu menurunkan dan mengontrol tekanan darah agar tetap stabil.

Hasil penelitian ini juga sejalan dengan penelitian yang di lakukan oleh Siti Binaiyati 2017, dimana hasil penelitian bahwa terdapat perbedaan tekanan darah sistolik dan diastolik, sebelum dan sesudah di berikan air kelapa muda. Sehingga dapat disimpulkan bahwa ada pengaruh terapi air kelapa muda terhadap tekanan darah pada penderita hipertensi di Mejing Wetan Gamping Sleman Yogyakarta. ${ }^{3}$

Penelitian ini juga sesuai dengan penelitian yang dilakukan oleh Heni Nurhayati 2017, bahwa ada perbedaan yang signifikan tekanan darah (baik sistolik maupun diastolik) pada lansia penderita hipertensi sebelum dan sesudah diberikan air kelapa muda di Desa Gogik Kecamatan Ungaran Barat Kabupaten Semarang, dengan p-value untuk sistol dan diastol $0,000<p(0,05)$. Ini menunjukkan bahwa setelah pemberian air kelapa selama 5 hari tekanan darah pada lansia kelompok intervensi sebagian besar cenderung mengalami penurunan. ${ }^{9}$

Hasil penelitian ini sejalan dengan pendapat Bogadenta (2013) bahwa air kelapa

\section{DAFTAR PUSTAKA}

1. Setiadi P. 2013. Efek Air Kelapa (Cocos Nucifera Linn) Terhadap Penurunan Tekanan darah. [Jurnal]. Bandung. Universitas Kristen Maranatha, Fakultas Kedokteran. muda dapat menormalkan tekanan darah. Kandungan kalium membantu tubuh untuk menyeimbangkan fungsi natrium dalam ketidakseimbangan tekanan darah yang normal. Kalium bertindak sebagai unsur penting yang mempertahankan kenormalan tekanan darah dalam tubuh manusia, hal ini berarti semakin memperkecil kemungkinan penyakit jantung dan hipertensi. Pengatur tekanan darah merupakan fungsi yang paling penting dari mineral ini. ${ }^{10}$

\section{KESIMPULAN DAN SARAN}

Hasil penelitian ini dapat disimpukan bahwa ada pengaruh pemberian air kelapa muda terhadap penurunan tekanan darah pada penderita hipertensi di Wilayah Kerja Puskesmas Lanrisang Kabupaten Pinrang. Dari hasil kesimpulan penelitian ini, disarankan bagi penderita hipertensi Penelitian ini diharapkan dapat menjadi salah satu metode terapi non farmakologis dalam menurunkan tekanan darah yang dapat diterapkan secara mandiri oleh pasien dan bagi peneliti selanjutnya diharapkan dapat melakukan penelitian dengan menggunakan variabel lain dengan desain penelitian yang lebih baik tentang terapi non formakologis dalam menurunkan tekanan darah tinggi.

https://www.google.co.id/url?q=http://reposit ory.maranatha.edu/12340/1/1010171_Abstrac t_TOC.PDF\&sa=U\&ved=2ahUKEwj105rsn MfdAhXIfisKHS1fD1oQFjAAegQIAhAB\& 
usg=AOvVaw3lWpT8Ra-fMcPuXZ_xnLs-.

[Diakses pada tanggal 30 Juni 2018].

2. Nurhikmah S. 2016. Pengaruh Pemberian Jus Mentimun (Cucumis Sativus) Terhadap Penderita Hipertensi di Kelurahan Lawowoi Kecamatan Watan Pulu Kabupaten Sidenreng Rappang. [Skipsi]. Pare-pare. Unuversitas Muhammadiyah Pare-pare.

3. Binaiyati S. 2017. Pengaruh Terapi Air Kelapa Muda terhadap Tekanan Darah Pada Penderita Hipertensi di Mejing Wetan Gamping SlemanYogyakarta. [Jurnal]. Yogyakarta. Universitas Aisyiyah Yogyakarta, Fakultas Ilmu Kesehatan. https://www.google.co.id/url?q=http://digilib. unisayogya.ac.id/2607/1/NASKAH\%2520PU BLIKASI.pdf\&sa=U\&ved=2ahUKEwiVgKC GmsfdAhVZWH0KHdHLC9IQFjAAegQIA BAB\&usg=AOvVaw0yt1T8_xeIDX914xERs Lw2. [Diakses pada tanggal 21 April 2018].

4. Farapti dan Safitri, S. 2014. Air Kelapa Muda Pengaruhnya terhadap Tekanan Darah. [Jurnal]. Surabaya. Universitas Airlangga Surabaya, Fakultas Kesahatan Masyarakat. Http/;//Www.Researchgate.Net/Publication/3 15096822_Air_Kelapa_Muda_Pengaruhnya_ Terhadap_Tekanan_Darah. [Diaskses pada tanggal 25 Mei 2018].

5. Lingga L. 2012. Terapi Kelapa Untuk Kecantikan Dan Kesehatan. Jakarta: PT Elex Media Komputindo, Gramedia.

6. Tricara G Dkk. 2014. Pengaruh Air Kelapa Muda terhadap Penurunan Tekanan Darah
Penderita Hipertensi di Desa Kauman Kecamatan Kabuh Kabupaten Jombang. [jurnal]. Jombang. Stikes Husada Jombang, Program Studi S-1 Keperawatan.

7. Buda E S. 2015. Perbedan Efektivitas Seduhan Daun Alpukat (Persea American Mill) dan Air Kelapa Hijau Muda (Cosos Nucifera Linn) terhadap Tekanan Darah Pada Wanita Menopause dengan Hipertensi. [Jurnal]. Surabaya. Akademi Kebidanan Griya Husada. https://www.google.co.id/url?q=http://jurnal. akbid-griyahusada.ac.id/files/ejournal/vol3_no1/e-journal-3-1-3. [Diakses pada tanggal $30 \mathrm{~J}$ uni 2018].

8. Farwati A. 2012.Pemberian Buah Pepaya terhadap Tekanan Darah Penderita Hipertensi di Wilayah Kerja Puskesmas Ngampilan Yogyakarta. [Jurnal]. Yogyakarta. Sekolah Tinggi Ilmu Kesehatan 'Aisyiyah Yogyakarta, Program Studi Ilmu Keperawatan.

Http://digilib.unisayogya.ac.id.[Diakses pada tanggal 25 Mei 2018].

9. Nurhayati H. 2017. Pengaruh Terapi Air Kelapa Muda Terhadap Tekanan Darah Pada Lansia Penderita Hipertensi di Desa Gogik Kecamatan Ungaran Barat Kabupaten Semarang. [Jurnal]. Semarang. Universitas Ngudi Wuloyo, Program Studi S1 Ilmu Keperawatan.https://www.google.co.id/url?q =https://www.scribd.com/document $/ 3703932$ 90/BABIII\&sa=U\&ved=2ahUKEwjC0fynMf 
dAhVSfH0KHXZEAiEQFjAAegQIBBAB\&

usg $=\mathrm{AOvVaw0N}-$

PKVFg4EO33tpKQAlMlO. [Diakses pada tanggal 29 Mei 2018].
10. Darmawan B. 2013. Diet Sehat Air Kelapa untuk Kecantikan dan Penyembuhan macammacam Penyakit. Yogyakarta: Media Pressindo. 


\section{LAMPIRAN}

Tabel 1. Distribusi Karakteristik Umur dan Jenis Kelamin Responden di Wilayah Kerja Puskesmas Lanrisang Kabupaten Pinrang

\begin{tabular}{ccc}
\hline Umur (tahun) & Frekuensi & Presentase (\%) \\
\hline $30-39$ & 6 & 11,5 \\
$40-49$ & 8 & 15,4 \\
$50-59$ & 20 & 38,5 \\
$60-69$ & 14 & 26,9 \\
$>70$ & 4 & 7,7 \\
\hline Total & 52 & 100,0 \\
\hline Jenis Kelamin & Frekuensi & Persentase $(\%)$ \\
\hline Laki-laki & 20 & 38,5 \\
Perempuan & 32 & 61,5 \\
\hline Total & 52 & 100,0 \\
\hline
\end{tabular}

Tabel 2. Distribusi Karakteristik Tekanan Darah Sistolik Responden Sebelum diberikan Air Kelapa Muda di Wilayah Kerja Puskesmas Lanrisang Kabupaten Pinrang

\begin{tabular}{ccc}
\hline Tekanan darah & Frekuensi & Persentase (\%) \\
\hline Optimal & 0 & 0 \\
Normal & 0 & 0 \\
Pra hipertensi & 0 & 0 \\
Hipertensi derajat I & 41 & 78,8 \\
Hipertensi derajat II & 11 & 21,2 \\
Hipertensi derajat III & 0 & 0 \\
\hline Total & 52 & 100,0 \\
\hline
\end{tabular}

Tabel 3. Distribusi Karakteristik Tekanan Darah Sistolik Responden Sesudah diberikan Air Kelapa Muda di Wilayah Kerja Puskesmas Lanrisang Kabupaten Pinrang

\begin{tabular}{ccc}
\hline Tekanan darah & Frekuensi & Persentase $(\%)$ \\
\hline Optimal & 3 & 5,8 \\
Normal & 12 & 23,1 \\
Pra hipertensi & 20 & 38,5 \\
Hipertensi derajat I & 17 & 32,7 \\
Hipertensi derajat II & 0 & 0 \\
Hipertensi derajat III & 0 & 0 \\
\hline Total & 52 & 100,0 \\
\hline
\end{tabular}


Tabel 4. Distribusi Karakteristik Tekanan Darah Diastolik Responden Sebelum diberikan Air Kelapa Muda di Wilayah Kerja Puskesmas Lanrisang Kabupaten Pinrang

\begin{tabular}{ccc}
\hline Tekanan darah & Frekuensi & Persentase (\%) \\
\hline Optimal & 0 & 0 \\
Normal & 2 & 3,8 \\
Pra hipertensi & 0 & 0 \\
Hipertensi derajat I & 25 & 48,1 \\
Hipertensi derajat II & 25 & 48,1 \\
Hipertensi derajat III & 0 & 0 \\
\hline Total & 52 & 100,0 \\
\hline
\end{tabular}

Tabel 5. Distribusi Karakteristik Tekanan Darah Diastolik Responden Sesudah diberikan Air Kelapa Muda di Wilayah Kerja Puskesmas Lanrisang Kabupaten Pinrang

\begin{tabular}{ccc}
\hline Tekanan darah & Frekuensi & Persentase (\%) \\
\hline Optimal & 1 & 1,9 \\
Normal & 16 & 30,8 \\
Pra hipertensi & 0 & 0 \\
Hipertensi derajat I & 25 & 48,1 \\
Hipertensi derajat II & 10 & 19,2 \\
Hipertensi derajat III & 0 & 0 \\
\hline Total & 52 & 100,0 \\
\hline
\end{tabular}

Tabel 6. Skor Rata-rata dan Standar Deviasi Pre Test-Post Test

\begin{tabular}{crrcc}
\hline $\begin{array}{c}\text { Tekanan } \\
\text { darah }\end{array}$ & $\begin{array}{c}\text { Skor rata-rata } \\
\text { pre test }\end{array}$ & $\begin{array}{c}\text { Skor rata-rata } \\
\text { post test }\end{array}$ & $\begin{array}{c}\text { Standar deviasi pre test } \\
\text { Sistolik }\end{array}$ & $\begin{array}{c}\text { Standar deviasi post } \\
\text { test }\end{array}$ \\
Diastolik & $94,49 \mathrm{mmHg}$ & $130,19 \mathrm{mmHg}$ & 8,771 & 9,598 \\
\hline
\end{tabular}

Tabel 7. Hasil Uji Wilcoxon Tekanan Darah Responden

\begin{tabular}{ccc}
\hline Test Statistik & $\begin{array}{c}\text { Sistolik sesudah }- \text { sistolik } \\
\text { sebelum }\end{array}$ & $\begin{array}{c}\text { Diastolik sesudah - diastolik } \\
\text { sebelum }\end{array}$ \\
\hline$Z$ & $-5.577^{\mathrm{b}}$ & $-4.820^{\mathrm{b}}$ \\
\hline Asymp. Sig. (2-tailed) &, 000 &, 000 \\
\hline
\end{tabular}

